\title{
Myocardial iron quantification using modified Look-Locker inversion recovery (MOLLI) T1 mapping at 3 Tesla
}

\author{
GC Camargo ${ }^{1 *}$, T Rothstein ${ }^{1}$, FP Junqueira ${ }^{1}$, E Fernandes ${ }^{1}$, RL Lima ${ }^{1}$, A Greiser ${ }^{4}$, R Strecker ${ }^{5}$, JA Lima ${ }^{2}$, SS Xavier ${ }^{3}$, \\ I Gottlieb ${ }^{1}$
}

From 16th Annual SCMR Scientific Sessions

San Francisco, CA, USA. 31 January - 3 February 2013

\section{Background}

Quantification of myocardial iron overload is critical for the management of patients with hemochromatosis. The effects of excess iron on $\mathrm{T} 1$ and $\mathrm{T} 2 *$ relaxation times correlate directly with tissue iron concentration. $\mathrm{T} 2 *$ became the clinical standard at $1.5 \mathrm{~T}$ as it can be easily obtained in a fast one breath-hold ECG gated multi-echo GRE sequence. At 3T, however, T2* quantification can be limited by pronounced susceptibility artifacts and signal sampling restraints due to shorter T2* times at higher iron concentrations. Since myocardial $\mathrm{T} 1$ time is up to thirty times longer than $\mathrm{T} 2 *$, it can be quantified with short echo-time inversionrecovery sequences even at high iron concentrations, and is less sensitive to susceptibility artifacts. We aimed to validate a recently developed modified LookLocker inversion recovery (MOLLI) sequence to quantify myocardial $\mathrm{T} 1$ in healthy controls and patients with iron overload at 3T, comparing to standard GRE based multi-echo $\mathrm{T}^{*}$ times at $1.5 \mathrm{~T}$.

\section{Methods}

A total of 15 normal volunteers and 7 chronic anemia patients (with a myocardial $\mathrm{T} 2 \%$ measure $<20 \mathrm{~ms}$ at $1.5 \mathrm{~T}$ in the last 2 years, five of these on iron chelating therapy) were prospectively enrolled. Myocardial T2* and T1 times were quantified in the same day, the former using a breath-hold multi-echo GRE sequence at $1.5 \mathrm{~T}$ (Symphony, Siemens, Erlangen, Germany) and the latter using the T1 mapping -MOLLI sequence at 3T (Verio, Siemens, Erlangen, Germany). All ROIs were placed at

\footnotetext{
'CDPI - Clínica de Diagnóstico por Imagem, Rio de Janeiro, Brazil Full list of author information is available at the end of the article
}

mid-interventricular septum, carefully avoiding the blood pool (Fig 1). All analyses were blinded.

\section{Results}

All patients had regular heart rhythm and all MRI exams showed diagnostic image quality. Volunteers and patients had significantly different mean myocardial $\mathrm{T} 2$ * ( $27.2 \mathrm{~ms}+/-3.9$ vs. $15.4 \mathrm{~ms}+/-6.3 \mathrm{p}<0.05$ respectively) and T1 times $1175.7 \mathrm{~ms}+/-22.8$ vs. $952.1 \mathrm{~ms}+/-173.2$ $\mathrm{p}<0.05$ respectively). $3 \mathrm{~T} \mathrm{~T} 1$ times strongly correlated with $1.5 \mathrm{~T} \mathrm{T2*}$ times ( $\mathrm{r}=0.95$ and Fig 2$)$. Using the $3 \mathrm{~T}$ T1 cut-off of $1130 \mathrm{~ms}$, sensitivity and specificity for 3T

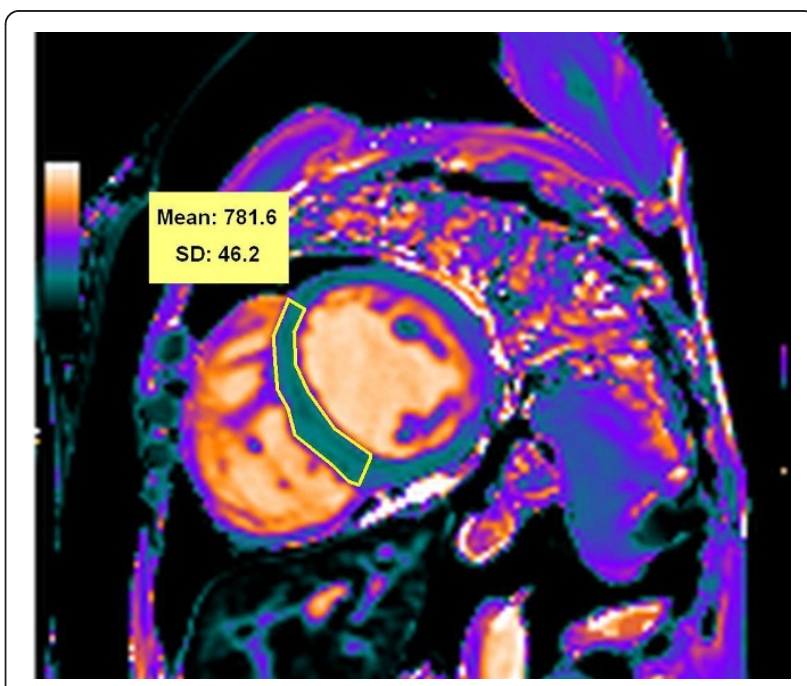

Figure 1 T1 map at 3T of a patient with iron overload showing reduced $\mathrm{T} 1$ time within the interventricular septum (781.6 $\mathrm{ms}$ ), in agreement with a significantly reduced $\mathrm{T} 2{ }^{*}$ time at $1.5 \mathrm{~T}(8.5 \mathrm{~ms}-$ not shown). 


\section{T1 at $3 \mathrm{~T}$ vs. T2* at $1.5 \mathrm{~T}$}

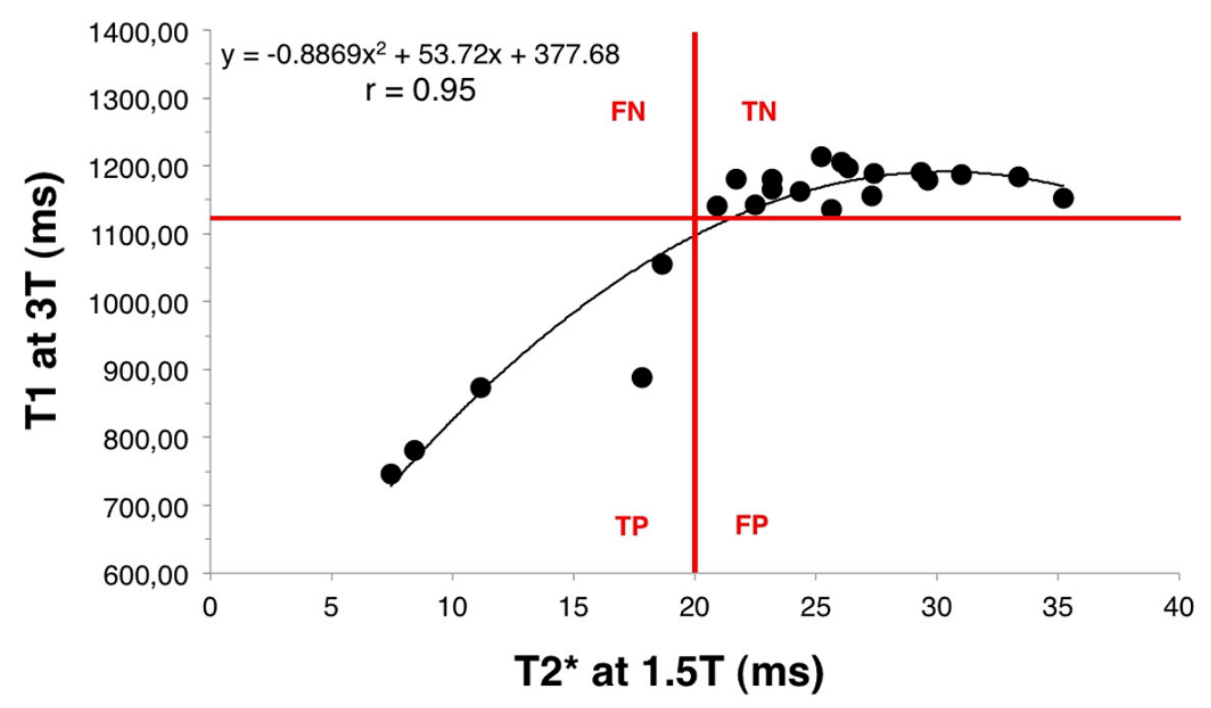

Figure 2 Correlation curve between $\mathrm{T} 1$ at $3 \mathrm{~T}$ and $\mathrm{T} 2^{*}$ at $1.5 \mathrm{~T}$. The whole data were best fitted by a quadratic curve with $\mathrm{r}=0.95$. Red lines delimitate true positives (TP), true negatives (TN), false positives (FP) and false negatives (FN) based on a T1 cutpoint of 1130 ms for the prediction of a $\mathrm{T}^{*}<20 \mathrm{~ms}$.

$\mathrm{T} 1$ to predict a $\mathrm{T} 2 * 20 \mathrm{~ms}$ at $1.5 \mathrm{~T}$ (standard reference) were both $100 \%$.

\section{Conclusions}

Myocardial T1 value obtained with a MOLLI sequence has excellent iron quantification capability at $3 \mathrm{~T}$.

\section{Funding}

Internal.

\section{Author details}

${ }^{1}$ CDPI - Clínica de Diagnóstico por Imagem, Rio de Janeiro, Brazil. ${ }^{2}$ Medicine/ Cardiology, Johns Hopkins University, Baltimore, MD, USA. ${ }^{3}$ Cardiology, Hospital Universitário Clementino Fraga Filho - UFRJ, Rio de Janeiro, RJ, Brazil. ${ }^{4}$ Siemens Healthcare, Erlangen, Germany. ${ }^{5}$ Siemens LTDA, Sao Paulo, SP, Brazil.

Published: 30 January 2013

doi:10.1186/1532-429X-15-S1-W8

Cite this article as: Camargo et al: Myocardial iron quantification using modified Look-Locker inversion recovery (MOLLI) T1 mapping at 3

Tesla. Journal of Cardiovascular Magnetic Resonance 2013 15(Suppl 1):W8.
Submit your next manuscript to BioMed Central and take full advantage of:

- Convenient online submission

- Thorough peer review

- No space constraints or color figure charges

- Immediate publication on acceptance

- Inclusion in PubMed, CAS, Scopus and Google Scholar

- Research which is freely available for redistribution

Submit your manuscript at www.biomedcentral.com/submit
C Biomed Central 